\title{
LEVEL OF INVESTMENT EXPENDITURE VERSUS CHANGES IN TECHNICAL LABOUR EQUIPMENT AND LABOUR EFFICIENCY IN AGRICULTURE IN POLAND
}

\author{
Dariusz Kusz, Eng $\mathrm{PhD}^{1}$ \\ Faculty of Management, Rzeszów University of Technology
}

\begin{abstract}
The aim of the paper is to analyse changes in the efficiency of the use of the labour factor and changes in the relation of production factors regarding the investment outlay level in individual voivodeships, in Poland, in 2002-2015. The research used the public statistics panel data from 2002-2015 (Local Data Bank). An increase in technical labour equipment, the level of investment outlays per one employed person in agriculture and an improvement in the efficiency of using the labour factor was found. At the same time, considerable regional diversification of investment activities, work equipment in fixed assets and labour productivity is still observed in Poland. The improvement of labour efficiency in agriculture is positively influenced by an increase in work technical equipment and the level of completed investments per one employee.
\end{abstract}

Keywords: investment, agriculture, labour efficiency, relation of production factors JEL codes: E32, E22

\section{INTRODUCTION}

There are various definitions of investment in subject literature. Starting from the theory of economics, Hirshleifer (1965) presented the most general and most frequently used definition of investment, which perceived investment as a renunciation of current consumption in order to achieve future uncertain benefits. This definition shows that investment requires expenditure and assumes obtaining certain benefits that are deferred in time. The investment characteristics mentioned above result in the process being burdened with risk. However, to maintain a solid foundation for development, implementation is necessary.
In the case of agriculture, production investments are of decisive importance and constitute one of the most important elements of long-term growth of farms. They are carried out mainly with a view to improve the competitiveness of an economic entity, to increase efficiency and the level of profit as well as to extend the scale of operations or start a new business. In addition, investment in agriculture provides general social benefits. It depends on the nature of the investment, however, such goals as reducing the negative impact of agriculture on the natural environment, animal welfare, the need to eliminate hunger in the world and making farming sustainable requires an increase in investment in agriculture (Žídková, Rezbová and Rosochatecká, 2011; Kusz, Gędek and Kata, 2015).

${ }^{1}$ Corresponding author: Powstańców Warszawy 10,35-959 Rzeszów, Poland, dkusz@prz.edu.pl, +4817 8651120 
The aim of the paper is to analyse changes in the efficiency of the use of the labour factor and changes in the realities of production factors when it comes to the level of investment outlays in individual voivodeships, in Poland, in 2002-2015.

\section{THEORETICAL BACKGROUND}

The basic objective of tangible investments is to improve efficiency. Production investment, implemented by agricultural farms, contributes to an increase in equipment in property, plant and equipment, which in turn leads to a change in the ratio of production factors, and thus a change in the manufacturing technique. It is particularly important to change the relation of capital to work as it enables an increase in work technical equipment, and consequently should lead to an increase in work efficiency. This is the foundation for a sustained increase in agricultural income. For this reason, the level of investment made to improve the efficiency in agricultural is of decisive importance. It is also worth paying attention to the fact that an increase in agricultural producers' income is the basis for an increase in savings, which in turn determines the continued investment activity of farmers. To indicate the significance of primary income growth, this relationship can be reversed. The increase in investment induces an increase in the value of production capital, which in turn improves the relation of capital to work, thanks to which there is an increase in labour productivity. This is a condition for the growth of agricultural income, which in turn may turn into savings and subsequent investment. For this reason, the value of implemented investment in agriculture, especially their level per one employee in this sector of the economy is of key importance for growth and development in the long term.

Among the economic factors exerting an influence on farmers' investment activity, one should also pay attention to the level of prices of agricultural products, prices of means for production, prices of production factors and their mutual relations. The observed trends in price level changes in long periods are particularly important. Chavas (2011), while analysing changes in prices of agricultural products (in real terms) in the USA over the last 100 years, noticed a lasting down- ward trend. A similar trend was also demonstrated by Huffman and Evenson (2001) and Czyżewski and Kułyk (2007) and who were analysing changes in prices of agricultural products and prices of products purchased by farmers (in real terms) in the USA. In addition, it was also pointed out that the rate of decline in prices of products sold by farmers was higher than the prices of inputs. This meant a permanent opening up of price scissors and deterioration of the farmers' income situation. In turn, in the studies by Runowski and Ziętara (2011), attention was paid to the relationship of prices of production factors and prices of agricultural products. It can be seen that the highest growth dynamic is demonstrated by labour costs, and then by prices of goods purchased by farmers. On the other hand, the lowest upward trend is shown by the prices of agricultural products sold by farmers.

The current tendency causes a decrease in unit profitability of agricultural production. Farmers, in order to generate income at the parity level, need to increase the scale of production and strive to increase economic efficiency. In turn, the change in the price ratio of agricultural production factors necessitates a change in applied production techniques (Wicki, 2016). In the discussed conditions, the rapid increase in labour costs, as compared to other production factors, necessitates the implementation of labour-saving production techniques, resulting in an increase in the relation of capital to work. The effect of this is the substitution of more and more expensive labour inputs with relatively cheaper capital.

\section{MATERIALS AND METHODS}

The empirical material for the analysis was the CSO (Central Statistical Office in Poland) statistical data for the years 2002-2015 (Local Data Bank). In order to preserve the comparability of figures expressed in monetary terms, fixed prices from 2015 were used, to this end the consumer price index (CPI) was applied. The following ratios were used in the analysis: the level of investment outlays was assessed on the basis of the ratio of the value of investment per one employed in agriculture, the index of technical labour equipment (gross value of fixed assets per one employed in agriculture) and the factor of labour ef- 
Proceedings of the 2018 International Scientific Conference 'Economic Sciences for Agribusiness and Rural Economy' No 1, Warsaw, 7-8 June 2018, pp. 315-320

ficiency calculated as gross value added per one employee in agriculture. The average annual dynamics of changes in the aforementioned ratios was determined on the basis of the following formula $\ln (\mathrm{Yn} /$ $/ Y 0) / n$, where 0 relate to 2002, and $n=13$ for 2015 . $\ln (Y n / Y 0) / n$, where 0 refers to year 2002, and $n=13$ for 2015 (Wicki, 2012).

\section{RESULTS AND DISCUSSION}

In this research, particular attention was paid to the level of technical labour equipment. This ratio informs us about the value of fixed assets per unit of work. Usually, a low value of this ratio adversely af- fects work efficiency (Gołaś and Kozera, 2008). The value of technical labour equipment in the analysed period, on average, in Poland, amounted to PLN 68.143 thousand (Table 1). At the same time, considerable regional diversity was found. The highest level of this ratio was characteristic of the West Pomeranian Voivodeship, and the lowest - the Lublin Voivodeship. Differences between these voivodeships was over 4.5 -fold. The technical labour equipment, in the analysed period, in Poland, increased by $43.3 \%$, while the average annual growth was at a level of $2.36 \%$. The largest increase in technical labour equipment was recorded in the Małopolska Voivodeship (a real increase of $93.6 \%$, average annual growth of $4.9 \%$ )

Table 1. Technical labour equipment and the level of investment outlays per one employed in agriculture, in Poland, in the years 2002-2015

\begin{tabular}{|l|c|c|c|c|c|c|}
\hline \multirow{2}{*}{ Specification } & \multicolumn{3}{|c|}{ Technical labour equipment } & \multicolumn{2}{c|}{ Investment outlays per one employed } \\
\cline { 2 - 7 } & $\begin{array}{c}\text { average annual } \\
\text { value } \\
\text { (PLN thous.) }\end{array}$ & $\begin{array}{c}\text { relative growth } \\
\text { (year 2002 } \\
\text { (100\%) }\end{array}$ & $\begin{array}{c}\text { average annual } \\
\text { growth } \\
(\%)\end{array}$ & $\begin{array}{c}\text { average annual } \\
\text { value } \\
\text { (PLN thous.) }\end{array}$ & $\begin{array}{c}\text { relative growth } \\
\text { (year 2002 } \\
\text { (100\%) }\end{array}$ & $\begin{array}{c}\text { average annual } \\
\text { growth } \\
\text { (\%) }\end{array}$ \\
\hline Poland & 68.14 & 143.3 & 2.36 & 14.05 & 161.5 & 3.69 \\
\hline Lower Silesia & 119.36 & 154.9 & 3.86 & 17.14 & 145.6 & 2.89 \\
\hline Kujawy-Pomerania & 76.33 & 128.4 & 1.31 & 12.23 & 207.9 & 5.63 \\
\hline Lublin & 43.74 & 146.6 & 2.33 & 8.21 & 204.4 & 5.50 \\
\hline Lubusz & 99.16 & 167.4 & 4.39 & 12.67 & 154.4 & 3.34 \\
\hline Łódź & 60.05 & 136.6 & 2.36 & 11.66 & 194.0 & 5.10 \\
\hline Małopolska & 36.56 & 193.6 & 4.90 & 12.71 & 188.8 & 4.89 \\
\hline Masovian & 65.17 & 124.9 & 0.46 & 19.69 & 113.2 & 0.96 \\
\hline Opole & 106.72 & 166.8 & 2.48 & 12.22 & 268.6 & 7.60 \\
\hline Podkarpacie & 40.10 & 172.3 & 4.07 & 11.52 & 192.7 & 5.04 \\
\hline Podlasie & 71.73 & 151.5 & 2.51 & 10.99 & 220.7 & 6.09 \\
\hline Pomeranian & 99.70 & 95.3 & -0.50 & 16.40 & 148.6 & 3.05 \\
\hline Silesian & 111.87 & 127.6 & 1.11 & 14.55 & 148.6 & 3.05 \\
\hline Świętokrzyskie & 38.83 & 106.2 & 0.04 & 9.27 & 129.0 & 1.96 \\
\hline Warmian-Masurian & 119.15 & 104.1 & 0.58 & 11.68 & 179.2 & 4.49 \\
\hline Wielkopolska & 96.42 & 172.2 & 3.60 & 14.75 & 179.7 & 4.51 \\
\hline West Pomeranian & 165.21 & 103.0 & 2.03 & 15.13 & 213.0 & 5.82 \\
\hline
\end{tabular}

Source: own calculations based on CSO Local Data Bank data. 
and in the Podkarpackie Voivodeship (a real increase of $72.3 \%$, average annual growth of $4.07 \%$ ). These were voivodeships, which were characterized by the lowest values of this ratio for the analysed period. At the same time, the Świętokrzyskie Voivodeship similarly had a low level of technical labour equipment, but real growth was low (only 6.2\%), as well as the average annual growth of $0.04 \%$ ). This may indicate the ongoing process of convergence of regional agriculture in terms of technical equipment, but this does not apply to all voivodeships. At the same time, large changes in the value of technical labour equipment were recorded in the Wielkopolska, Lubusz and Opole Voivodeships, which in 2002-2015 were characterized by a higher than average level of this ratio in Poland. A decrease in the value of fixed assets per one employee was noted only in the Pomeranian Voivodeship (a downward decline of $0.5 \%$ ), but also a small change was recorded for the West Pomeranian Voivodeship (a real increase of 3\%), i.e. in voivodeships with a high level of technical equipment.

The increase in technical labour equipment is a consequence of the level of investment outlays per one employee. The annual average value of this ratio, in agriculture, in Poland, was PLN 14.05 thousand and in 2015 the level of investment per capita in agriculture was higher by $61.5 \%$ than in 2002 (Table 1). The Masovian, Lower Silesia, Pomeranian, West Pomeranian, Wielkopolska and Silesian Voivodeships were characterized by the highest investment activity. And the lowest investment activity was in the Lublin and Świętokrzyskie Voivodeships. The difference in the value of investment outlays per one employed among the voivodeships with the highest value of this ratio was the Masovian Voivodeship, and the voivodeship with lower investment activity - found in the Lublin Voivodeship was 2.4-fold. It is worth noting, however, that agriculture in the Lublin Voivodeship was characterized by a high average annual growth rate $(5.5 \%)$, while in the Masovian Voivodeship it was only $0.96 \%$.

The improvement of technical labour equipment should lead to an increase in work productivity, as a relation between production results per unit of work resource. As a measure of production results, gross value added was adopted, which as an income cate- gory is available in public statistics. Gross value added is one of the most objectified categories of business effectiveness assessment used in the assessment of work efficiency. Its specificity results from the fact that it measures productivity in terms of value-added by human capital in comparison to material costs coming from outside (Góral and Rembisz, 2017).

In agriculture, in Poland, labour productivity in 2015 was higher than in 2002 by $44.1 \%$ (Table 2). The average annual dynamics of changes in labour productivity, in agriculture, in Poland was at a level of $2.81 \%$. In all analysed voivodeships, there was an increase in work efficiency, with the exception of the Lower Silesia Voivodeship, where work efficiency in 2015 was lower than in 2002 by $8.4 \%$. The largest increase in this ratio in 2015, comparing to 2002, was recorded in the Podlasie, Masovian, Pomeranian and Lubusz voivodeships. The average annual value of the labour efficiency index, in Poland, in the years 2002-2015, was at a level of PLN 16.99 thousand. However, some significant regional differences were found. The lowest level of productivity at work was in Podkarpackie, Małopolska, Świętokrzyskie and Lublin Voivodeships, and the highest in West Pomeranian, Lubusz and Warmian-Masurian Voivodeships. Deep regional differences in labour productivity in agriculture may continue in Poland due to the large variation in dynamics of change. Faster productivity growth is particularly desirable in fragmented agricultural regions.

Statistical analysis of the interdependencies between the examined features of agriculture in particular regions indicates a positive correlation between the analysed variables (Table 3 ). This proves positive feedback between investment activity in agriculture expressed by the value of investment outlays per one employed, and the efficiency of using the labour factor and technical labour equipment. An increase in the level of investment outlays in agriculture in Poland enables change in the production technique and substitution of labour with capital, which consequently leads to an improvement in the efficiency of the use of the labour factor and an increase in its profitability. In the next step, it allows for the creation of savings, which can then turn into investment creating a stable basis for further development. 
Proceedings of the 2018 International Scientific Conference 'Economic Sciences for Agribusiness and Rural Economy' No 1, Warsaw, 7-8 June 2018, pp. 315-320

Table 2. Work efficiency in agriculture in Poland in the years 2002-2015

\begin{tabular}{|c|c|c|c|}
\hline \multirow[b]{2}{*}{ Specification } & \multicolumn{3}{|c|}{ Gross value added per one employee in agriculture } \\
\hline & $\begin{array}{l}\text { average annual value } \\
\text { (PLN thous.) }\end{array}$ & $\begin{array}{c}\text { relative growth } \\
(\text { year } 2002=100 \%)\end{array}$ & $\begin{array}{c}\text { average annual growth } \\
(\%)\end{array}$ \\
\hline Poland & 16.99 & 144.1 & 2.81 \\
\hline Lower Silesia & 20.41 & 91.6 & -0.67 \\
\hline Kujawy-Pomerania & 23.08 & 120.7 & 1.45 \\
\hline Lublin & 9.83 & 169.8 & 4.07 \\
\hline Lubusz & 31.39 & 130.8 & 2.07 \\
\hline Łódź & 16.66 & 141.4 & 2.66 \\
\hline Małopolska & 6.93 & 130.0 & 2.02 \\
\hline Masovian & 23.80 & 183.0 & 4.65 \\
\hline Opole & 21.29 & 110.5 & 0.77 \\
\hline Podkarpacie & 4.63 & 133.2 & 2.21 \\
\hline Podlasie & 17.42 & 194.2 & 5.11 \\
\hline Pomeranian & 24.49 & 170.8 & 4.12 \\
\hline Silesian & 14.66 & 126.5 & 1.81 \\
\hline Świętokrzyskie & 9.76 & 138.2 & 2.49 \\
\hline Warmian-Masurian & 31.12 & 139.8 & 2.58 \\
\hline Wielkopolska & 26.50 & 126.5 & 1.81 \\
\hline West Pomeranian & 34.94 & 127.6 & 1.88 \\
\hline
\end{tabular}

Source: own calculations based on CSO Local Data Bank.

Table 3. Correlation matrix of technical labour equipment, investment outlays per one employed and gross value added per one employee in agriculture

\begin{tabular}{|l|c|c|c|}
\hline Variables & $\begin{array}{c}\text { Technical labour } \\
\text { equipment }\end{array}$ & $\begin{array}{c}\text { Investment outlays per } \\
\text { one employed }\end{array}$ & $\begin{array}{c}\text { Gross value added } \\
\text { per one employee in } \\
\text { agriculture }\end{array}$ \\
\hline Technical labour equipment & 1 & - & - \\
\hline Investment outlays per one employed & $0.824^{*}$ & 1 & - \\
\hline $\begin{array}{l}\text { Gross value added per one employee in } \\
\text { agriculture }\end{array}$ & $0.742^{*}$ & $0.870^{*}$ & 1 \\
\hline
\end{tabular}

* significant for $P<0.05$.

Source: own calculations based on CSO Local Data Bank. 


\section{CONCLUSIONS}

Investing is a key element that exerts a fundamental influence on the social and economic development of a country. Implemented investment determines the strength or weakness of a given economy, and at a micro-scale, determines the competitive position of an enterprise. In this research it was found that:

1. Technical labour equipment in 2002-2015 increased, while in Poland there is still a significant regional variation in the level of this ratio, which may affect differences in the level of economic efficiency in agriculture.

2. The level of investment outlays per one employee in agriculture is regionally differentiated, while the value of this ratio in the analysed period also increased, which is, on the one hand, related to the investment needs of agriculture in Poland, but on the other forced by the need to substitute labour with capital. In addition, Poland's accession to the structures of the European Union and the availability of financial resources for the modernization of agriculture have had a positive impact on the activation of investment activities in agriculture.

3. The effect of changes in technical labour equipment and the level of investment outlays per one employee in agriculture is growing labour productivity in agriculture, whereby this productivity is also significantly diversified regionally. The issue of faster growth of labour productivity in agriculture in Poland should be prioritized within the framework of economic policy as the weakness of agriculture in this area hinders regional income convergence.

4. A statistical analysis of the correlations has shown that to improve the efficiency of using work in agriculture (gross value added per one employee in agriculture), it is important to improve the technical equipment of labour ( $\mathrm{R}$ - Spearman correlation coefficients -0.742 ) and increase investment activity expressed by investment outlays per one employed ( $\mathrm{R}$ - Spearman correlation coefficients $-0.870)$.

\section{REFERENCES}

1. Chavas, J.P. (2011). Agricultural Policy in a uncertain world. European Review of Agricultural Economics, 38 (3), pp. 383-407.

2. Czyżewski, A., Kułyk, P. (2007). Makroekonomiczne uwarunkowania polityki rolnej w USA po 1990 roku [Macroeconomic Determinants of Agricultural Policy in the USA After 1990]. Roczniki Naukowe SERiA, 9 (1), pp. 83-88.

3. Gołaś, Z., Kozera, M. (2008), Strategie wydajności pracy w gospodarstwach rolnych [Strategies of Labour Productivity in Agricultural Farms]. Journal of Agribusiness and Rural Development, 1 (7), pp. 73-87.

4. Góral, J., Rembisz, W. (2017). Wynagrodzenie i wydajność pracy w rolnictwie polskim na tle pozostałych krajów Unii Europejskiej [Remunerations and Labour Productivity in Agriculture Against a Background of Other European Union Countries]. Zeszyty Naukowe SGGW. Ekonomika i Organizacja Gospodarki Żywnościowej, 119, pp. 119-139.

5. Hirshleifer, J. (1965). Investment Decision under Uncertainty - Theoretic Approaches. The Quarterly Journal of Economics, 74, pp. 509-536.

6. Huffman, W.E., Evenson, R.E. (2001). Structural and productivity change in US agriculture, 1950-1982. Agriculture Economics, 24, pp. 127-147.

7. Kusz, D., Gędek, S., Kata, R. (2015). Macroeconomic Determinants of the Dynamics of Investment in Agriculture (Case of Poland). Scientific Papers. Management, Economic Engineering in Agriculture and Rural Development, 15 (2), pp. 171-178.

8. Runowski, H., Ziętara, W. (2011). Future role of agriculture in multifunctional development of rural areas. Abstract. Applied Studies in Agribusiness and Commerce, 5 (1-2), pp. 29-38.

9. Wicki, L. (2012). Convergence of Labour Productivity in Agriculture in the European Union. Economic Science for Rural Development. In: Proceedings of the International Scientific Conference, 27, pp. 279-284.

10. Wicki, L. (2016). Zmiany produktywności czynników wytwórczych w polskim rolnictwie [Changes in factor productivity in Polish agriculture]. Zeszyty Naukowe SGGW. Ekonomika i Organizacja Gospodarki Żywnościowej, 116, pp. 149-160.

11. Žídková, D., Rezbová, H., Rosochatecká E. (2011). Analysis of Development of Investments in the Agricultural Sector of the Czech Republic. Agris on-line. Papers in Economics and Informatics, 3 (1), pp. 33-43. 